\title{
SUNDAY OBSERVANCE LEGISLATION IN ALBERTA ROBERT CURTIS*
}

\begin{abstract}
With the increasing emphasis of secularization in our society, and the declining importance of religious activities, Sunday observance legislation may have lost its original impetus. Mr. Curtis, in this article, examines the historical development and the present state of Sunday observance legislation in terms of its continued validity. By analyzing the recent cases of Boardwalk Merchant's Mart and Robertson \& Rosetanni $v$. The Queen, he raises important questions as to whether such legislation is constitutionally valid Dominion Legislation, either as criminal legislation, or in view of the Canadian Bill of Rights. But even though he concludes that the decline of religious significance of the legislation and its resulting secularization may have removed it from the domain of federal power, Mr. Curtis suggests that such legislation may not be either appropriate provincial legislation in this "day and age", or even valid in terms of the Alberta Bill of Rights.
\end{abstract}

It is monstrous, it is grotesque, that Parliament can create a crime of that which is not basically so.

- Mr. Justice Riley²

Mr. Average Canadian Citizen wakes up on Sunday morning bleary-eyed from his Saturday night frolic but more refreshed than usual by his extra long sleep. This day is unlike others. It is somehow brighter, more cheerful, and altogether quieter. Mr. Citizen looks forward to a day of leisure, some chores, perhaps a picnic or drive in the park, most probably an hour of church, certainly several hours of television. There are, however, no stores open in which to buy groceries or perhaps a new suit. The real estate man won't sell him that house he has been looking for. The tavern keeper won't help him "blow" his week's wages. And the Province won't sell him his new license plates. Perhaps he can get those things done during lunch next week. In the meantime Mr. Citizen must rest. Even his neighbor, the kosher delicatessen owner, is resting. "My neighbor must be lazy", says $\mathrm{Mr}$. Citizen to himself, "He's been resting since sunset Friday!"

What makes Canada rest? "Blue laws", that's what - Sunday observance legislation - the "Lord's Day" Act. This article will explore that statute and other similar legislation, their history, what they say, and what the courts and others have said about them. At the end the writer will offer some comments of his own. Throughout there will be questions which will remain unanswered: What is religious freedom? What authority do Parliament and the provincial legislatures have to enact these laws? Do they really discriminate? Are they necessary?

\section{THE HISTORY OF SUNDAY OBSERVANCE LAWS}

\section{Pre-Confederation}

Sunday laws are nothing new. As long ago as 321 A.D., the Emperor Constantine issued an edict that commanded all city people and tradesmen to rest on Sunday, though farmers could attend their fields and those engaged in acts of a "public nature" were exempted. This and the other early Roman laws owed their origins, however, to pagan influences, not Christian. The day of rest was not referred to as the Lord's Day, or even Sunday, but rather as "The Day of the Sun", a reference to the mythological god Apollo.

In 380 A.D., Christianity was made the official religion of the Empire and the first statute commanding rest on the "Lord's Day" was promulgated in 386.

- B.A. (McGill), LL.B. (Alta.).

1 Boardwalk Merchandise Mart Ltd. v. The Queen [1972] 6 W.W.R. 1 at 30 (Alta. S.C.) rev'd [1973] I W.W.R. 190 (Alta. A.D.). 
But pagan references remained in addition to religious ones. It was not until 469 that the first completely Christian Lord's Day Act appeared. These laws were prohibitive in nature and forbade business, legal proceedings, entertainments, and even the celebration of the Emperor's birthday if it should fall on a Sunday.

With the demise of the Roman Empire and the emergence of the papaldominated Holy Roman Empire, the Sunday laws became deeply religious, harsh and dogmatic. Their purpose was not the secular one of rest and relaxation, but the religious one of freeing the people to attend church and pray. In 585 the Second Council of Macon declared a statute providing for punishments which included the "wrath of God and the unappeasable anger of the clergy" (probably resulting in excommunication) and even, in some cases, whipping.

The early Saxon laws followed the format of those of the Holy Roman Empire, but were somewhat more secular in nature. Corporal punishment gave way to fines, and there was even a provision for the payment of half of the fine to an informant. The prohibitions stressed business transactions, but there were also specific prohibitions on certain forms of recreation, entertainment and travel. The laws were still largely Christian-oriented, however, and prayer as well as rest was expected on Sundays.

After the Norman Conquest the Sunday laws began to merge with the Biblical commandments to observe the Sabbath and the Church took full responsibility for them. They were not very successful and Sunday business and recreation remained popular in spite of the penalties involved. This state of affairs was reversed with the enactment of the first major English statute, the Sunday Fairs Act, 1448. ${ }^{2}$ This Act prohibited the popular "fairs", or market-place gatherings, on every Sunday and Holy Day except the last four Sundays of the harvest season. ${ }^{8}$

The reformation denoted a change in Sunday legislation. It became a device of political control in the battles between the Tudor kings and the Roman Church. In addition to closing business, the statutes required open adherence to the activities of the established church of England. The non-observation of religious exercises resulted in severe penalties, including death. However, Elizabeth, following the bloody reign of her Catholic sister Mary, wished to unite the country and thus modified the harshness of the statutes and even allowed the public exhibition of Sunday sports, although there was no abandonment of strict conformity to the English Church. With the reign of the Stuarts came a further relaxation in the laws. Certain sporting activities were permitted to be engaged in, but only by those who had been in attendance at church that morning. The puritan clergy did not welcome these changes, and they eventually became a factor in the fall of the monarchy later in the seventeenth century.

The first modern English Act dealing with Sunday observance was passed in 1625." This Act declared that the "keeping of the Lord's Day is a principal part of the true service of God" and it prohibited "meetings, assemblies or concourse of people out of their owne Parishes on the Lord's Day, within this realme of England, or any the Dominions thereof, for any sports or pastimes whatsoever". In 1627,5 a further statute was passed extending the prohibitions to travel, driving of cattle and killing or selling of meat. These Acts remained in force in England until $1969 .^{\circ}$

227 Henry 6.

3 The exemption was removed by 13 \& 14 Vict., c. 23.

4 An Act for Punishing Divers Abuses Committed on the Lord's Day Called Sunday, 1 Car. 1 , c. 1 .

- An Act for the Further Reformation of Sunday Abuses Committed on the Lord's Day Commonly Called Sunday, 3 Car. 1, c. 2.

- The Statute Law (Repeals) Act, 1969, 18 Eliz. 2, c. 52. 
During the Interregnum (1649-1660) the Puritans, led by Cromwell, passed the most oppressive of Sunday legislation. On Sundays there were no shops, no sports, no travellers, no dancing or profane singing, no washing of clothes. In fact, it was even a crime to be found "vainly and profanely walking"! To enforce the laws, certain persons were authorized to enter dwelling houses to look for "Sabbath-breakers". Nor were these laws confined to England, for the Puritans took them with them across the ocean, and New England had extremely harsh "blue laws".

After the restoration of the Monarchy, the force of the legislation abated somewhat. The most important piece of legislation for some time to come was passed in 1677.? This prohibited "any worldly labour or business of work of . . . ordinary calling", travel and the serving of legal documents. Works of "necessity and charity" were excepted, as was the preparing of food at home or in restaurants. While this legislation appears largely religious in character, it should be noted that Blackstone ${ }^{8}$ considered it an admirable piece of social legislation providing for rest, relaxation, worship and good citizenship.

In 1780 an Act $^{\circ}$ was passed which outlawed public entertainments for which an admission was charged and all public debates on any subject. Heavy fines were provided for the keepers of houses where these activities took place and the Act may be considered as political as it was religious. The legislators were concerned that the working classes might assemble for political purposes on their one-day-off each week.

These are by no means the only Sunday observance statutes. Others dealt with topics as diversified as chimney sweeps and the baking of bread. But they show the general trends which the law has taken on the subject and provide the background for our own Canadian statutes. It should be remembered that most of the above statutes are probably in force in Alberta, a fact which was extremely important at one time due to the provision in the Lord's Day Act ${ }^{10}$ preserving common law prosecutions. However, since Parliament abolished offences under English statute law in 1955, ${ }^{11}$ any argument that the statutes are "in force" is largely academic.

\section{Legislation Since Confederation}

For some time after Confederation it was uncertain as to where constitutional power to enact or amend Sunday observance legislation lay. The English legislation had been judicially characterized as "criminal"12 but no one knew the breadth of that term as used in s. 91(27) of the B.N.A. Act. The provinces apparently felt that they had authority under $92(13)$ or $92(16)$, for the Province of Ontario not only re-enacted the pre-Confederation statute of Upper Canada ${ }^{18}$ but added many amendments to it. ${ }^{14}$ Other statutes of Ontario also contained provisions respecting Sunday. ${ }^{18}$ Parliament, if it had any objections, did not

7 An Act for the Better Observation of the Lord's Day Commonly Called Sunday, 29 Chas. 2, c. 7.

IV Blackstone's Commentaries 63 (1897 Lewis ed.).

- An Act for Preventing Certain Abuses and Profanation on the Lord's Day, Called Sunday, 21 George 3, c. 49.

10 Lord's Day Act, R.S.C. 1970, c. L-13, s. 15.

11 S.C. $1953-54$, c. 51 , s. 8 (b).

12 R. v. Barnes (1880) 45 U.C.Q.B. 276.

13 An Act to Prevent the Profanation of the Lord's Day in Upper Canada, 1859 C.S.U.C., c. 104, re-introduced with amendments as R.S.O. 1877 , c. 189.

141885,48 Vict., c. 44 ; R.S.O. 1887, c. 203 ; 1896, 59 Vict., c. 62 ; 1897, 60 Vict., c. 14.

${ }^{25}$ E.g., The Ontario Shop's Regulation Act, 1888, 51 Vict., c. 33, s. 2; An Act Respecting Shops and Places Other Than Factories, 1897, 60 Vict., c. 51, s. 40. 
voice them, but instead listed the Ontario statute as "doubtful" in the 1886 First Revised Statutes of Canada.

In 1903, all doubt was removed. The Judicial Committee of the Privy Council ruled that the Ontario statute was ultra vires. ${ }^{16}$ Sunday observance legislation was criminal in nature, and it was the "whole field" of criminal law which was reserved by 91 (27) to Parliament. Further confirmation appeared in 1905. ${ }^{17}$ This froze the legislation until altered by Parliament, and for Alberta this meant the 1780 Act of George III was the primary Sunday law in force.

Parliament, however, proved an unwilling legislator. Resolutions to enact a Sunday observance statute were introduced in 1878, 1879, 1884,1890, 1891 and 1892 by John Charlton, Liberal Member for North Norfolk, an outspoken leader of the Lord's Day Alliance of Canada, which had world-wide affiliations. None of these bills were successful, but they attracted great publicity and provided an exhaustive exposition on the existing state of the law and social practices around the world (tainted no doubt with a good measure of propaganda). The fact that the bills were highly religious in character was not the measure of their failure; rather, successive governments had grave doubts as to their constitutionality. The pragmatics of inter-governmental relations were no doubt a factor as well.

A Parliamentary committee was established, and the Lord's Day Alliance kept up a strong attack. After the green light of 1903, success was inevitable, though, like all government bills, slow in arrival. One of the issues which blocked passage was whether an exemption ought to be granted to those who celebrated a day other than Sunday as the Sabbath. Such a measure was introduced but defeated by a vote of 79 to 57 . It was noted by the majority that such an exemption might destroy the essence of the Bill, especially if persons artificially changed faiths so as to reap the benefits of a monopoly Sunday business. Other reasons given were that the Bill didn't actually require religious attendance and therefore didn't interfere with freedom of religion. Moreover, the large majority of the country celebrated Sunday as the Sabbath. It was also noted that the state observes monogomy without any objection that it violates the religious freedom of polygamists.

Other debates ensued concerning the title of the legislation, the discretion given the Attorney General of the province as to prosecution, and the phrase, except as provided herein, or in any provincial Act or law now or hereafter in force". It was argued that the latter provision was in essence a delegation of powers to the provincial legislatures. However, it was finally rationalised as little more than recognition that Parliament did not want to declare unlawful that which a province might decide to be a "civil right" of a person. As is indicated later in this article, the line between "refraining from declaring as a crime that which the provinces have indicated to be a right" and "leaving to the provinces the power to decide that an otherwise unlawful activity is lawful" is slight indeed.

The Lord's Day Act ${ }^{18}$ was given Royal Assent on July 13, 1906 and came into force on March 1, 1907. Since then it has gone through four consolidations ${ }^{10}$ and only two minor amendments. ${ }^{20}$

${ }^{16}$ A.-G. for Ontario v. The Hamilton Street Ry. Co. [1903] A.C. 524.

${ }^{17}$ Re Legislation Respecting Abstention From Labour on Sunday (1905) 35 S.C.R. 581. 18 S.C. 1906 , c. 27.

19 R.S.C. 1906 , c. 153 ; R.S.C. 1927 , c. 123; R.S.C. 1952 , c. 171; R.S.C. 1970 , c. L - 13.

${ }^{20}$ S.C. 1948, c. 58 which gave power to the Deputy Attomey General of the province, in addition to the Attorney General, to consent to prosecutions; S.C. 1966-67, c. 69, s. 94 which modified the "work of necessity or mercy" to include any transportation undertaking; S.C. 1953-54, c. 51 (Crim. Code) amended s. 15 de facto by abolishing common law prosecutions. 
In 1912, the Supreme Court of Canada held in Ouimet v. Bazin ${ }^{21}$ that a Quebec Act which prohibited theatrical performances for gain on Sunday was, like the Ontario Act, ultra vires. The Province argued that it had authority to pass the legislation by virtue of the section in the Lord's Day Act exempting activities permitted by a province. But the court noted that the province was here prohibiting an activity, not allowing it, and hence was entering the field of criminal law. A similar disposition of a municipal bylaw was made by the court in Parish of St. Prosper v. Rodrigue ${ }^{22}$ in 1918.

In $1924,{ }^{23}$ the Privy Council allowed Manitoba legislation permitting certain Sunday excursions even though excursions generally were unlawful by the Lord's Day Act. It was held that this was a law "now or hereafter in force" sufficient to come within the exempting clause. Refering to the Hamilton Street Ry. Co. case, Lord Blanesburgh stated:24

The Board, dealing there with the Ontario Act as a whole - as an Act which created offences and imposed penalties for their commission - held that such a statute was part of the criminal law, and, as such, exclusively within the competence of the Parliament of Canada. But the Board was not considering the power of a Provincial Legislature to recognize what may be called the non-observance of Sunday as distinct from its assumption of power to enforce by penalties or punishment the observation of that day. And the two things are very different. Legislative permission to do on Sunday things or acts which persons of stricter sabbatarian views might regard as Sabbathbreaking is no part of the criminal law where the acts and things permitted had not previously been prohibited. Such permission might aptly enough be described as a matter affecting 'civil rights in the Province' or as one of 'a merely local nature in the Province'. Nor would such permission necessarily be otiose. The border-line between the profanation of Sunday - which might at common law be regarded as an offence and therefore within the criminal law — and the not irrational observance of the day is very indistinct.

This case was followed by the Supreme Court in the 1959 case of Lord's Day Alliance of Can. v. A.-G. of B.C. ${ }^{25}$ where it was argued that the provincial permission there differed from the one in the 1924 case in that it was an activity forbidden by the English observance statutes and hence was within the sphere of criminal law. The court rejected this argument with reference to the 1955 changes in the Criminal Code ${ }^{26}$ which put an end to prosecutions under common law or the statutes of England. Since there are now no laws in force touching the observance of Sunday except the Lord's Day Act, and as there is no "domain" of criminal law, it cannot be said that the Province has legislated with respect to criminal law if the legislation does not run afoul of that Act.

In 1955, the Supreme Court extended the scope of Sunday observance legislation by ruling that a Quebec statute empowering municipal councils to order by by-law the closing of stores on New Year's Day, the festival of Epiphany, Ascension Day, All Saints Day, Conception Day and Christmas Day was ultra vires. ${ }^{27}$ The court noted that these were all Holy or "Feast" days and derived their sole significance from religion. The statute was not designed to provide for additional holidays, as evidenced by the lack of provision for a holiday-over should the day fall on a Sunday. Mr. Justice Kellock stated: ${ }^{28}$

If Sunday observance legislation was designed to enforce under penalty the observance of a day by reason of its religious significance, there is no basis for distinction, in my

21 (1912) 3 D.L.R. 593

22 (1918) 40 D.L.R. 30.

${ }^{23}$ Lord's Day Alliance of Canada v. A.-G. for Man. [1925] A.C. 384.

24 Id. at 392.

25 [1959] S.C.R. 497.

26 Supra, n. 11.

27 Henry Birks and Sons v. City of Montreal [1955] S.C.R. 799.

$28 \mathrm{Id}$. at 823. 
opinion, historically or otherwise, with respect to legislation directed to the enforcement of the observance of other days from the standpoint of their significance in any religious faith.

Kellock J. also felt the legislation, even if not criminal law, was beyond the jurisdiction of a provincial legislature as being in respect of freedom of religion guaranteed by the Freedom of Worship Act, 1852.20 Mr. Justice Rand's judgment was even wider in scope and of great interest to the entire question of freedom of religion: ${ }^{30}$

.. . these considerations show equally that the statute is enacted in relation to religion; it prescribes what is in essence a religious obligation. ... In this aspect, for the reasons given by me in the case of Saumur v. City of Quebec, as legislation in relation to religion the provision is beyond provincial authority to enact (emphasis added).

In 1963, the Supreme Court heard Lieberman v. The Queen. ${ }^{31}$ The legislation in question in that case was a by-law of the municipality of St. John, N.B. which specified that bowling alleys and other types of licensed premises were to close between twelve at night and six the next morning, "or on Sunday". The court distinguished the prior cases by indicating that the by-law was aimed at a valid regulatory scheme within the power of the province to enact, and the mere addition of the words above quoted would not be sufficient to make it Sunday legislation and thus a part of the criminal law.

Also, in 1963 the Supreme Court dealt, in Robertson \& Rosetanni v. R., ${ }^{32}$ with the contention that the Lord's Day Act conflicted with the new Canadian Bill of Rights ${ }^{33}$ in that it "abridged or infringed" freedom of religion. Ritchie J., speaking for the majority, held that "freedom of religion" as safeguarded by the Bill of Rights was that freedom which Parliament had earlier (in section 1) declared to "exist and have existed" in Canada at the passage of the Bill. His Lordship, referring to the cases in which freedom of religion had been held to exist in Canada, noted that the Lord's Day Act had never been held to violate freedom of religion or had otherwise been questioned, and held, therefore, that it did not conflict with the Bill. He also noted that while the purpose of the Act was clearly religious (as it must be if it is to be constitutionally valid) ${ }^{34}$ the effect was "purely secular and financial" and in no way interfered with the right of a person to worship freely.

Mr. Justice Cartwright (as he then was) delivered a vigorous dissent, in which he declared: ${ }^{35}$

... that this is an infrigement of religious freedom I do not doubt. . . A law which on solely religious grounds, forbids the pursuit on Sunday of an otherwise lawful activity differs in degree, perhaps, but not in kind from a law which commands a purely religious course of conduct on that day, such as for example, the attendance at least once at divine service in a specified church.

Having found that there was a conflict between the Act and the Bill, Mr. Justice Cartwright then went on to hold that the Bill must prevail, rendering the Act inoperative. In the later case of The Queen v. Drybones, ${ }^{36}$ he openly declared that this position was wrong, while the majority, including Ritchie J., agreed with his initial conclusion. There was no indication in Drybones, however, that Cartwright $\mathrm{J}$. considered himself in error as to the substantive conflict between the Lord's Day Act and the Bill of Rights.

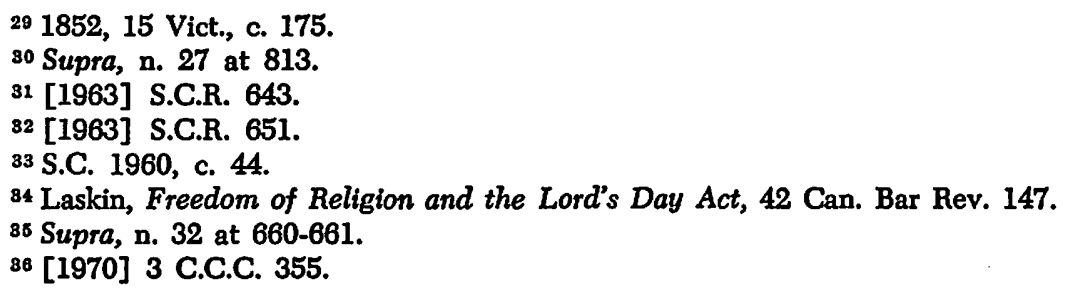


The most recent attack on the federal legislation came in Boardwalk Merchandise Mart Ltd. v. The Queen. ${ }^{87}$ At trial, Mr. Justice Riley was asked to declare the Lord's Day Act ultra vires on three grounds:

(1) The definition of criminal law to the extent that it reflects public policies is a matter which varies with the circumstances of the age, i.e., if Sunday observance legislation ever was criminal law, it no longer falls within the criminal law definition, however broad it may be.

(2) The legislation itself is in pith and substance labour legislation due to a watering down of the absolute character of the legislation.

(3) The Act offends s. 1(b) of the Canadian Bill of Rights.

In a thoroughly researched exposition of the history of the legislation and the authorities, His Lordship came to the conclusion that the Act was not a part of the criminal law as it has come to be in 1972. He noted that the proper test for ascertaining whether a piece of legislation is within the subject of criminal law is that laid down in the "Duff-Rand test": is the legislation designed to suppress a "public evil" and to prevent "harmful effects" upon the public? As there is no established religion in Canada, and as the acts which are prohibited in the legislation are acts which are intrinsically perfectly lawful, there is no evil against which the Act is directed. Therefore, it is not a valid part of the criminal law.

Riley J. also found the Act to be in pith and substance labour legislation. He noted the large number of activities exempted by the provinces from the general prohibitions imposed in the Act. These exemptions were enacted in fact to regulate commercial enterprise and provide for repose and recreation in the labour force. All that remains of the Act is a secular restraint on labour as a means of providing for a uniform day of rest. "It is trite law that labour relations is within the ambit of legislation of the provincial governments." 38

On the Bill of Rights question, Riley J. gave no definitive answer but certainly displayed sympathy to Cartwright J.'s position. On appeal to the Appellate Division of Alberta, the case was reversed. ${ }^{30}$ However, the court did not say that Riley J. was wrong in principle, but merely on authority. The court felt that they were bound by the Hamilton Street $R y$. Co. case and, citing authority for the necessity of applying the rules of stare decisis, said, "the respondents' arguments can only be dealt with in the Supreme Court of Canada".40 Leave to appeal to that court was refused by Fauteux C.J.C., Abbott and Pigeon J.J. without reasons. ${ }^{41}$

\section{A SUMMARY OF THE PRESENT SUNDAY OBSERVANCE LEGISLATION}

\section{Federal}

The Lord's Day Act is not a complicated piece of legislation. Indeed, one can easily learn to deplore its imprecision and lack of guidance as to what is and what is not prohibited. As we shall see, the courts have added greatly to the confusion.

The prohibitions, of course, all relate to activities which take place on "the Lord's Day". Section 2 defines this expression as "midnight on Saturday night [ending] at midnight on the following night". Depending upon one's religion, one might question this definition, but it would appear to be fairly well entrenched.

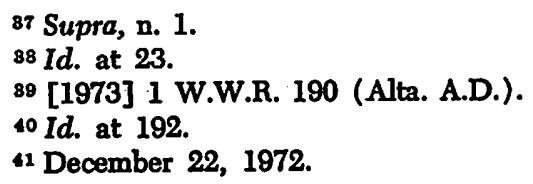


Section 4 makes it unlawful for anyone to sell or offer for sale or purchase: any goods, chattels, or other personal property, or any real estate, or to carry on or transact any business of his ordinary calling, or employ any other person. In 1961, the Supreme Court of Canada gave a very wide interpretation to this section. ${ }^{42}$ The accused was charged with operating a coin-laundry on Sunday. He defended by tendering evidence that neither he nor his employees were actually in attendance at the laundry; the machines were fully automatic and patrons were instructed by means of signs as to their use. Eight judges of the Court rejected his arguments, holding that it was unnecessary to be actually present in order to be "carrying on business". Cartwright J. dissented, holding that the only purpose of the statute was to prevent persons from working on Sunday, and unless the accused actually did some positive act in the furtherance of the business, the statute was not violated.4s

It has also been held that the leasing of a business in return for a share of the Sunday receipts is an offence under this section. ${ }^{44}$ But, apparently the lessor: is not in violation if he leases on a weekly or monthly basis, especially to a non-profit association. ${ }^{45}$

In the recent case of Neider v. Carda of Peace River, ${ }^{46}$ the Supreme Court held that a transfer of land registered during the week but actually executed on Sunday and falsely dated was "illegal and unenforceable" by virtue of s. 4. The Appellate Division of Alberta ${ }^{47}$ had previously found that the parties were in pari delicto and thus the transferor could not recover the land from the transferee. However, Hall J. decided: ${ }^{18}$

The transaction in question came squarely within said s. 4 because Respondent was in the real estate and loan business and in what it did on December 18,1966, it was carrying out its ordinary business in realizing on an overdue security. The Respondent cannot rely on its own illegal agreement, even though Appellant was a party thereto, to hold the titles it acquired by registering what were in reality false documents.

It can be seen from this decision that the consequences of carrying on business on Sunday can be considerably greater than the penalties provided in the Act. ${ }^{-i}$

Section $\mathbf{5}$ states that it is unlawful to require any employee engaged in certain kinds of communications, any kind of industrial process, transportation, or "work of his ordinary calling" to work on Sunday unless a complete day of rest is provided within the next six. It is submitted that this section cannot by any stretch of imagination, be considered religious in purpose and is thus not properly. criminal law. ${ }^{49}$ Insofar as it extends prohibitions to labour falling within the provincial powers, it is probably ultra vires.

Section 6 makes it unlawful to "engage in any public game or contest for gain ... or be present thereat, or to provide, engage in, or be present at any performance or public meeting, elsewhere than in a church, at which any fee is charged, directly or indirectly. ..." Subsection (2) prevents the proprietor from circumventing the section by charging for transportation to the performance rather than at the door. In Winnipeg Film Society v. The Queen, ${ }^{30}$ it was held

12 Gordon v. R. [1961] S.C.R. 592.

43 It was not argued that the laundry was a "work of necessity or mercy".

44 . v. Bol-O-Drome Ltd. (1943) 80 C.C.C. 82.

45 . v. Bol-O-Drome Ltd. (1944) 82 C.C.C. 161.

16 [1972] S.C.R. 678.

47 [1971] 2 W.W.R. 379.

48 Supra, n. 46 at 685.

49 See the section dealing with constitutional validity of federal legislation, supra.

${ }^{\circ 0}$ (1964) 44 D.L.R. (2d) 126 (S.C.C.). 
that a society which had an annual membership fee was not charging admission, even indirectly, at the door, and therefore did not violate the section. The courts have also ruled that the mixing of permitted activities with prohibited ones does not render the latter lawful.:1

Section 7 makes it unlawful to "run, conduct, or convey by any mode of conveyance any excursion on which passengers are conveyed for hire", principally for pleasure and "passengers so conveyed shall not be deemed to be travellers within the meaning of this Act". There do not appear to be any cases on this section and it does not seem to have caused much concern. Indeed, "excursions" appear to be commonplace today, especially in places such as National Parks. Presumably, these would involve violations of sections 4 or 6 as well and prosecutions would probably result under them instead.

Other prohibited activities include the importation and sale of foreign newspapers and the discharge of firearms "so as to disturb persons observing the Lord's Day". One can only speculate as to how close the hunter must be to the worshipper, whether the observation of the Lord's Day refers to attendance at service or mere rest, or whether the parties have to have any contact at all. Depending upon one's religious beliefs, the mere discharge of the weapon is a violation of sanctity. Nor must the activity actually take place for there to be a violation under the Act, for the mere advertisement of a prohibited activity is a crime, even if it is proposed to take place outside of Canada.

At this stage it would be useful to refer to a fundamental exemption found in sections 4, 6, and 7: "except as provided by any provincial Act or law in force on or after the 1st day of March 1907". ${ }^{22}$ It is under this excepting power that the provinces, including Alberta, have passed Lord's Day Acts of their own permitting certain activities otherwise unlawful under the federal Act. It has been determined that such legislation must be permissive and not prohibitive, must be initially valid under the provinces' constitutional powers, and must not permit an activity which is otherwise criminal. ${ }^{53}$

Another major exemption is that found in section 11 of the Act:

Notwithstanding anything herein contained, any person may on the Lord's Day do any work of necessity or mercy, and for greater certainty, but not so as to restrict the ordinary meaning of the expression 'work of necessity or mercy', it is hereby declared that it shall be deemed to include the following classes of work. . . .

The section continues to outline 24 specific examples of such works of necessity or mercy. The layman will perhaps have a great deal of difficulty in following the reasoning of Parliament as to the element of "necessity" or "mercy" in some of these examples, and it is therefore understandable that the bulk of litigation concerning the Act has centred on this question. The Supreme Court has given little guidance in the matter and the cases show a generally haphazard approach. It would appear that the definition of necessity and mercy is quite wide, and the Alberta Appellate Division decided long ago that the list enumerated in section 11 should be taken as a general guide for determining whether other activities fall within the exception. ${ }^{34}$ If analogy upon analogy is to be drawn, it is conceivable that little activity will remain unlawful in the future.

51 E.g., the offering of a musical performance with meals. See Johnson v. Jay-Marc Enterprises Ltd. (1965) 53 W.W.R. 436 (Sask. C.A.).

52 The original wording was "except as provided herein, or in any provincial Act or law now or hereafter in force." The change was made in the 1970 consolidation and was apparently deemed of a clerical nature intended to render the effective date more apparent.

${ }^{53}$ Lord's Day Alliance of Can. v. A.-G. for Man., supra, n. 23; Lord's Day Alliance of Can. v. A.-G. for B.C. [1959] S.C.R. 497.

54 R. v. Cummings [1925] I D.L.R. 1126. 
One major question which has received conflicting consideration in the courts is whether the necessity or mercy need be that of the seller ${ }^{55}$ or the purchaser ${ }^{56}$ in the case of offering goods or services. The list given in the section is so diverse that the true answer could be either or both.

A further analysis of the meaning of the phrase would provide a diminishing return. The courts have held that the following constitute works of "necessity or mercy":

The supply of gasoline, ${ }^{57}$

Operating tractor-trailers in transit at the start of the day, ${ }^{58}$

Transport of perishable goods, ${ }^{59}$

Opening a coin-operated car wash, ${ }^{60}$

Opening a coin laundry, ${ }^{61}$

Preparing food and drink consumed on the premises, ${ }^{62}$

The sale of milk, ${ }^{63}$ bananas, or root beer. ${ }^{64}$

Yet the following have been held to be outside the scope of the exception:

The supply of gasoline, ${ }^{65}$

Operating tractor-trailers, ${ }^{86}$

Opening a skating rink for hire to member teams of a junior league, ${ }^{67}$

The sale of groceries, ${ }^{68}$ cigarettes, ${ }^{60}$ toothpaste, magazines, records, ${ }^{70}$ candy and apples. ${ }^{71}$

It is hoped that the writer will not be faulted for what may be just a faint touch of cynicism.

The penalties prescribed in the Act are not onerous. In the case of an individual, the fine is one to forty dollars and costs. An employer is liable to a fine of between 25 and 100 dollars, and a corporation from 50 to 250 dollars on first offence and up to 500 dollars for any subsequent offence.

However, section 16 provides that leave must be obtained for all prosecutions from the Attorney General or the Deputy Attorney General of the province wherein the offence occurred. This was originally incorporated to prevent the Act from becoming an instrument of persecution. Unfortunately, the fears of some Parliamentarians that the Act would fall into disrespect if not applied evenly and to all alike would have appeared to come true in some jurisdictions. There seem to be no cases on the question, but it is likely that someone will attack the provision in the future on the ground that it violates the Bill of Rights in denying equal protection of (subjection to?) the law. It may also deny due

os R. v. Wells (1911) 24 O.L.R. 77; R. v. Bortnick (1937) 69 C.C.C. 309.

${ }^{s e}$ R. v. Ninos (1928) 50 C.C.C. 155; R. v. Kent [1925] I D.L.R. 1117; R. v. Cummings, supra, n. 54.

${ }^{57} R$. v. Cummings, supra, n. 54.

58 R. v. Pacific Inland Express Ltd. (1959) 27 W.W.R. 588.

so R. v. Zavitz Bros. Ltd. [1961] O.W.N. 247.

60 R. v. Mueller (1966) 55 W.W.R. 245.

61 R. v. Coin Launder-All Ltd. (1960) 31 W.W.R. 262.

62 R. v. Wells, supra, n. 55; George v. City of Charlottetown [1932] 2 D.L.R. 443.

63 R. v. Bortnick, supra, n. 55.

64 R. v. Ninos, supra, n. 56.

6s R. v. Johnson (1949) 8 C.R. 365.

${ }^{66}$ R. v. Maislin Bros. Transport Ltd. (1969) 5 D.L.R. (3d) 646.

er R. v. Icelandia [1947] O.R. 761.

68 R. v. Bortnick, supra, n. 55.

69 R. v. Ninos, supra, n. 56.

70 R. v. Sunalta Drugs Ltd. (1964) 1 C.C.C.(NS) 286.

71 R. v. Kent, supra, n. 56. 
process of the law, though this is doubtful. The 60 day limitation period is a further, though somewhat less forceful, form of statutory protection.

By section 15, the Act is not to be construed as altering in any way the common law as it existed on March 1, 1907. Concurrent prosecution can be brought "under any other Act or law applicable to the offence charged". It is interesting to note that the 1970 consolidation changed the wording to clarify the operative date, as it did in other sections, without regard to the fact that the 1955 changes in the Criminal Code ${ }^{72}$ repealed this section de facto, if not de jure. Section 8 of the Code now provides that no person can be convicted of an offence at common law or under a statute of England. Since the existing Sunday observance legislation was of little, if any, civil consequence, it can be said to have no force today.

\section{Provincial}

Under the Lord's Day Act, the provinces are entitled to pass legislation permitting activities which would otherwise be unlawful under sections 4,6 or 7 of the federal Act. In 1969, Alberta passed such an Act, the Alberta Lord's Day Act. ${ }^{73}$ This Act provides that in any municipality, improvement district or "special area", a petition may be brought by 10 per cent of the electors, or 2000 of them, whichever is lesser, requesting the passage of a Sunday by-law. The Act provides a procedure for publication of notice of the petition, its passage and repeal. A council may pass a by-law on its own motion, but may not repeal one without a further petition, which cannot be brought for at least three years.

Section 4 of the Act outlines the activities which may be permitted by way of a Sunday bylaw:

(1) When a Sunday by-law is in force and subject to its provisions, it is lawful in the municipality, or in the part or parts thereof specified in the by-law, for any person after 1:30 o'clock in the afternoon, to provide, engage in or be present at (a) any game, contest or sport,

(b) any exhibition of an educational, artistic or cultural nature,

(c) any theatrical performance, concert, recital, lecture or other performance, and (d) any exhibition of moving pictures,

or such of them as are specified in the by-law, and which but for this Act would be unlawful under section 6 of the Lord's Day Act (Canada).

(2) When subsection (1) applies, it is lawful for a person to do or engage any person to do any work, business or labour on a Sunday in connection with an activity allowed under this section which but for this Act would be unlawful under section 4 of the Lord's Day Act (Canada).

Section 5 provides that the by-law may not allow horse racing, dog racing or boxing contests.

While the Province may not have power to enact plenary Sunday legislation, it still has many provisions which are merely parts of a general regulatory scheme and thus within its authority under the "aspect" doctrine. An example of this type of provision is found in the Liquor Licensing Act ${ }^{74}$ which closes liquor vendors and most outlets on Sundays. Since Hodge v. The Queen, ${ }^{75}$ the validity of this particular legislation has been unquestioned. In fact, the silence on the matter by the Ontario Law Reform Commission ${ }^{7 \theta}$ would indicate that Sunday closing of liquor stores, unlike the closing of shops, is not even considered Sunday observance legislation.

72 S.C. $1953-54$, c. 51 , s. $8($ b).

73 R.S.A. 1970 , c. 221.

74 R.S.A. 1970 , c. 212 , s. 71 and regulations thereunder, 154/58.

75 (1883) 9 App. Cas. 117.

${ }^{76}$ Ontario Law Reform Commission, Report on Sunday Observance Legislation (1970). 
However, shop closing legislation has been bitterly opposed and variously upheld or defeated upon whether it is or is not part of a general regulatory scheme. Examples of such regulatory legislation now existing and presumably valid include:

(1) s. 67 of the Land Titles Act, ${ }^{77}$ which renders contracts for the sale of real property made on Sunday void.

(2) s. 5 of the Sale of Goods Act ${ }^{78}$ which makes a similar disposition of contracts for the sale of personal property.

(3) The Wildlife Act ${ }^{79}$ which prohibits the hunting of big game on Sunday except in certain areas.

(4) The Billiard Rooms Act ${ }^{80}$ which closes such establishments on Sundays as well as weeknights (a municipal by-law may open them on Sunday after 1:30 P.M.).

(5) The Municipal Government Act ${ }^{81}$ which permits municipalities to pass by-laws closing shops, businesses or industries on Sunday.

Part III of the Labour Act ${ }^{82}$ provides for days of rest in the labour force but does not single out Sundays, as do some provinces, by commanding rest "wherever possible on Sunday". ${ }^{83}$

\section{THE CONSTITUTIONAL VALIDITY OF THE FEDERAL LORD'S DAY ACT}

\section{Does the Subject Matter Fall Within Criminal Law?}

There have been statutes in this country since long before Confederation passed for the express purpose of safeguarding the sanctity of the Sabbath (Sunday), and since the decision in Attorney General for Ontario v. Hamilton Street Ry. Co., [1903] A.C. 524; 2 O.W.R. 672; 7 C.C.C. 326 , it has been accepted that such legislation and the penalties imposed for its breach, constitutes a part of the criminal law in its widest sense and is thus reserved to the Parliament of Canada by s. 91(27) of the British North America Act. ${ }^{81}$

Notwithstanding formidable judicial pronouncements such as that recited above, Mr. Justice Riley held in Boardwalk Merchandise Mart Ltd. v. The Queen ${ }^{85}$ that "safeguarding the sanctity of the Sabbath" was not a legitimate purpose to which the Federal criminal law power could attach and hence the Lord's Day Act was ultra vires. Though reversed on appeal, the Appellate Division preferred to rely upon the shield of stare decisis, and the substantive matter was not dealt with. However, to those of us with a more academic inclination, or to those who agree with the learned Justice that "law is a living, changing, and breathing thing", 86 the matter is worthy of at least a cursory examination.

The various stores comprising the Boardwalk Merchandise Mart were charged with violation of the Lord's Day Act, presumably section 4, which prohibited the stores from offering goods for sale or otherwise carrying on their business on Sunday. It is no secret to residents of Edmonton that this prosecution was the direct result of pressure against the Boardwalk by various merchants'

77 R.S.A. 1970 , c. 198.

78 R.S.A. 1970 , c. 327.

79 R.S.A. 1970 , c. 391 , ss. $11(13), 28$.

80 R.S.A. 1970 , c. 28 , s. 13.

81 R.S.A. 1970 , c. 246 , ss. $231-233$.

82 S.A. 1973, c. 33.

83 See e.g., The Employment Standards Act, R.S.M. 1970, c. E-110, s. 36.

84 Ritchie J. speaking in Robertson \& Rosetanni v. R., supra, n. 32 at 656.

86 Supra, n. 1.

86 Id. at 29. 
associations in the city which alleged unfair competition. Were this not the case, it is doubtful whether the Attorney General would have invoked his discretion to prosecute, ${ }^{87}$ at least if the Ontario experience is any indicator for Alberta. ${ }^{88}$ Of the three major arguments put forth by the Boardwalk, the one most extensively dealt with by the court was: ${ }^{89}$

The definition of criminal law to the extent that it reflects public policies is a matter which varies with the circumstances of the age, i.e., if Sunday observance legislation ever was criminal law, it no longer falls within the Criminal law definition, however broad it may be.

Riley J., gave due regard to A.-G. for Ont. v. Hamilton Street Ry. Co., ${ }^{90}$ wherein the Privy Council held that "It is the criminal law in its widest sense that is reserved . . . " and Re Jurisdiction of Province to Legislate Respecting Abstention from Labour on Sunday ${ }^{91}$ in which the Supreme Court of Canada said: ${ }^{92}$

The day, commonly called Sunday, or the Sabbath, or the Lord's Day, is recognized in all Christian countries as an existing institution, and ... legislation having for its object the compulsory observance of such day or the fixing of rules or conduct (with the usual sanctions) to be followed on that day, is legislation properly falling within the views expressed by the Judicial Committee in the Hamilton Street Railway reference before referred to and is within the jurisdiction of the Dominion Parliament.

Not content to rely upon these passages, however, his Lordship went on to note that there is no indication in either of them as to "why the protection of Sunday as a day of religious significance was assumed to be a matter of criminal law".9s Three alternatives are suggested by the cases.

The first explanation is that religious observance is a matter of criminal law merely by virtue of its historical treatment as such. Riley J. found, however, that this view had been rejected by the Supreme Court of Canada in O'Grady v. Sparling, ${ }^{94}$ Lord's Day Alliance of Canada v. A.-G. of B.C., ${ }^{95}$ Provincial Secretary of P.E.I. v. Egan, ${ }^{06}$ and Goodyear Tire \& Rubber Co. of Canada Ltd. et al. v. The Queen. ${ }^{97}$ In these cases, the concept of the criminal law as a "static domain, defined by reference to the common law or the statutory law of the United Kingdom and Canada" was rejected. Furthermore, His Lordship felt that "if the scope of s. 91(27) is not limited to those matters that traditionally were dealt with under the label of 'Criminal Law', it must follow that a federal law derives no necessary validity from its historical antecedents".08 He cited Boucher v. The $K_{i n g}{ }^{90}$ as an example in which the Supreme Court had modified the common law on the basis of the changing conditions of society. "It would be strange, indeed, if the passing of history can affect a modification in the essential elements of a crime but not in the boundaries of criminal law itself."100

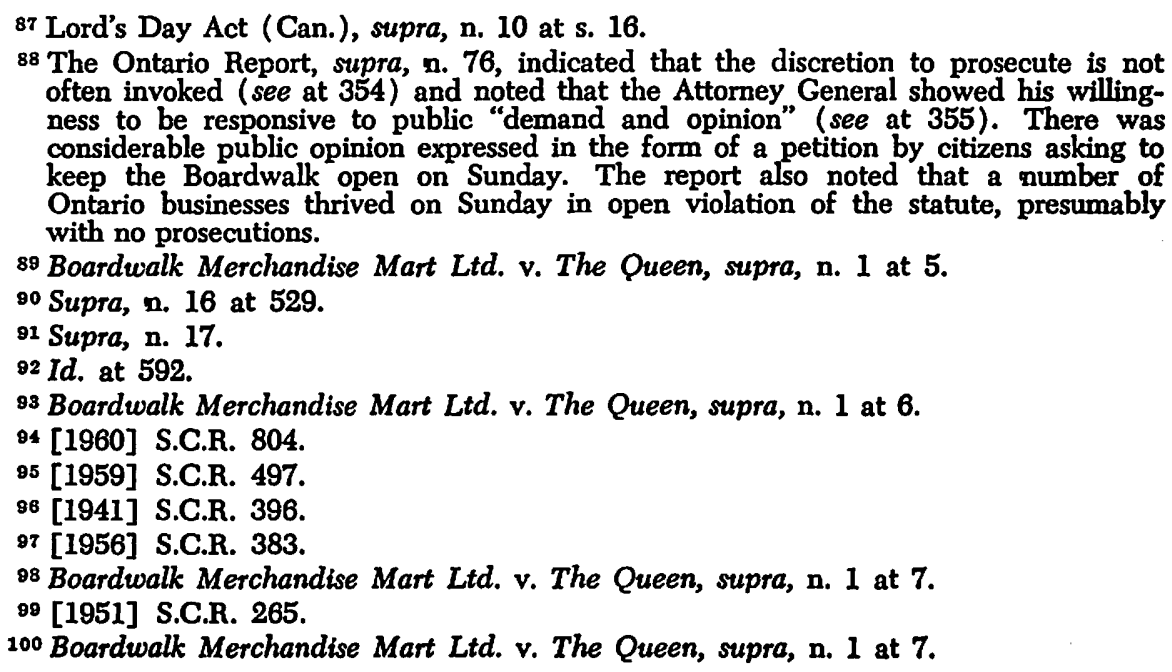
ness to be responsive to public "demand and opinion" (see at 355). There was considerable public opinion expressed in the form of a petition by citizens asking to Ontario businesses thrived on Sunday in open violation of the statute, presumably with no prosecutions.

${ }^{89}$ Boardwalk Merchandise Mart Ltd. v. The Queen, supra, n. 1 at 5.

90 Supra, n. 16 at 529.

91 Supra, n. 17.

92 Id. at 592.

9s Boardwalk Merchandise Mart Ltd. v. The Queen, supra, n. 1 at 6.

o4 [1960] S.C.R. 804.

95 [1959] S.C.R. 497.

${ }^{96}$ [1941] S.C.R. 396.

97 [1956] S.C.R. 383.

${ }^{98}$ Boardwalk Merchandise Mart Ltd. v. The Queen, supra, n. 1 at 7.

90 [1951] S.C.R. 265.

100 Boardwalk Merchandise Mart Ltd. v. The Queen, supra, n. 1 at 7. often invoked (see at 354) and noted that the Attorney, General showed his willingkeep the Boardwalk open on Sunday. The report also noted that a number of 
The second possible explanation is one put forth by Lord Atkin in Re Combines Investigation Act and s. 498 of the Criminal Code:101

The criminal quality of an act cannot be discerned by intuition; nor can it be discovered by reference to any standard but one: Is the act prohibited with penal consequences?

His Lordship rejected this argument, again quoting from O'Grady v. Sparling:102 A provincial enactment does not become a matter of criminal law merely because it consists of a prohibition and makes it an offence for failure to observe the prohibition. Riley J., unfortunately, overemphasises this point with the following observation: ${ }^{103}$

For this reason, the Hamilton Street Ry. case cannot be accepted as good law today if it was decided on the basis suggested by Lord Atkin; that is, that no further inquiry is necessary once it is determined that the Province has attached penal sanctions to a prohibition.

This paragraph is confusing because His Lordship appears to be saying that the Hamilton Street $R y$. case could not have been decided upon the principles put forth by Lord Atkin while, of course, it is quite obvious that the decision could have been so premised. However, it is submitted that what Riley J. meant was that if the attachment of penal consequences is alone sufficient to make the legislation criminal, then the case would never have reached the Privy Council nor have been argued there with such strength. Surely Lord Atkin's proposition is far too simplistic. Moreover, Riley J. felt that it emphasised the wrong aspect of the criminal law power and "is an untenable extreme for a federal constitution". ${ }^{104}$ The possibility would be far too great that such a doctrine would enable Parliament to encroach upon provincial matters with impugnity.

For Mr. Justice Riley the third explanation is the only tenable one. The "primary object [must be] the promotion of public order, safety and morals and not the regulation of civil rights as between subject and subject". ${ }^{105}$ His Lordship found that such a definition restricts the criminal law power as to its purpose, regardless of subject matter: ${ }^{106}$

Neither the subject matter of the legislation, nor the annexation of a penalty to prohibition, is a sufficient indicium of criminal legislation. The subject must be dealt with by the Dominion for a purpose which proceeds from certain defined objects.

In ascertaining what those defined objects are, Riley J. refers to what he calls the "Duff-Rand Test". In Re Combines, Duff J. described the objects of criminal law: ${ }^{107}$

They are concerned primarily not with rights, with their creation, the conditions of their exercise, or their extinction; but with some evil or some menace, moral or physical, which the law aims to prevent or suppress through the control of human conduct.

In the Margarine case, ${ }^{108}$ Rand J. used similar language and found that the products aimed at by the legislation there in question were "free of deleterious effects and, accordingly, there was nothing of a general or injurious nature to be abolished or removed"109 and he declared the legislation outside the criminal law.

Having established that the true limits of the criminal law power are as established by the "Duff-Rand Test", Riley J. goes on to note that the Lord's Day Act only proscribes activities which are not intrinsically harmful. Indeed, the illegal activities are laudable on any other day of the week. What, therefore,

101 [1931] A.C. 310 at 324.

102 Supra, n. 94 at 810.

103 Boardwalk Merchandise Mart Ltd. v. The Queen, supra, n. 1 at 9.

104 Id. at 8.

105 Per Locke J. in Johnson v. A.-G. of Alta. [1954] S.C.R. 127 at 150.

108 Boardwalk Merchandise Mart Ltd. v. The Queen, supra, n. 1 at 10.

107 Supra, n. 101 at 413.

${ }_{108}$ Reference Re Section 5(a) of the Dairy Industry Act [1949] S.C.R. 1. 109 Id. 
is the evil or menace, moral or physical, which the legislation aims to suppress? His Lordship felt that there is no such evil in a state which has no lawfully established religion requiring legislative protection. Were Canada to have, like England, any semblance of an established religion it might be possible to set up the observance of that religion as a virtue which the law may command. Yet the cases point out that we have no such established religion. ${ }^{110}$ Therefore, the arguments resting upon English law, as proof that the criminal law can deal with religion, are not applicable.

With the above as a background, Riley J. agrees with all the cases before him that the Lord's Day Act deals with religion. Yet while the courts in those other cases had held steadfastly to that determination in order to uphold the Act's constitutional validity (it is to be remembered that it is only in its relation to religion, and therefore criminal law, that the Act is competent of Parliament $^{111}$ ), His Lordship uses it to declare the Act ultra vires: ${ }^{112}$

The Lord's Day Act, then, is a statute which compels respect for a day which has no significance apart from that accorded to it by the statute. Parliament has not recognized and sought to remedy a public evil; it has created the evil by statutory enactment. In substance, the Lord's Day Act is not unlike the legislation struck down by the Privy Council in Attorney General for Ontario y. Reciprocal Insurers; . . . Non-observance of Sunday, like censure of government [referring here to Boucher v. The King], ought not by itself to be regarded as criminal. Far from constituting an evil, diversity in political, social and religious matters is 'of the essence of our life'.

In furtherance of his argument that there is no evil to which Parliament has directed the legislation, Riley J. notes that this is "class legislation", in that it prefers the Christian religious precepts to others. Such legislation had been found to be outside the proper scope of the criminal law in the Margarine case. Moreover, can it be said that Parliament really considered the non-observation of the Sabbath to be a crime when it gave the provinces the power to declare certain forms of non-observation not to be a crime? His Lordship dismissed an argument to the contrary based upon the case of Russell v. The Queen ${ }^{113}$ by saying that, in that case, Parliament had clearly identified the evil which it wished to suppress. The local option provision was merely to enable the provinces to accept or reject the sanctions employed by Parliament. In the Act at Bar, the effect of the provincial enactments would be to declare an activity Parliament had identified as a crime not to be a crime. To do so would be to deprive the legislation of its criminal character and show that, in substance, this was not criminal law at all.

The remainder of this part of Riley J.'s judgment concerns the argument put forth by the Boardwalk that the cases which hold that religion is within the criminal law are based upon an erroneous view that Christianity is part of the law of the realm. One would have thought that this contention was fully accepted by his Lordship, perhaps even by necessity, in the foregoing analysis, yet to be certain as to his position it is dealt with again. In short, while His Lordship might concede that the state is based upon Christian ideas, that is not to say that those ideas have been elevated to the stature of a legal institution.

The second argument directed at the court by the Boardwalk was to the effect that even if the Lord's Day Act was valid criminal law in 1906, it has become so watered-down by 1972 as to be in pith and substance labour legislation, and no longer criminal law. In accepting the argument as put forth, His Lordship states: ${ }^{114}$

\footnotetext{
110 Riley J. refers to Chaput v. Romain et al. [1955] S.C.R. 834 and Saumur v. Quebec [1953] 2 S.C.R. 299.

111 See e.g., Laskin, supra, n. 34 at 150.

112 Boardwalk Merchandise Mart Ltd. v. The Queen, supra, n. 1 at 14.

118 (1882) 7 A.C. 829.

114 Boardwalk Merchandise Mart Ltd. v. The Queen, supra, $\mathrm{n}$. 1 at 25.
} 
We have now come to accept as proper many of the things which religion condemned as sinful at one time.... To examine the Lord's Day Act within this framework, it would become absurd to suggest that the statute is intended for a religious purpose. . . . This manner of assessment of the statute would merely bring to a logical conclusion the gradual secularization of the courts, beginning with the removal of the jurisdiction of the ecclesiastical courts to the common-law courts and the courts of equity. This would remove all suggestion that non-Christians profane the Christian religion by not observing the Christian religion.

In one sense, it may be argued that Riley J. is not really addressing himself to a new argument, but rather proceeding on with the earlier one that the legislation has lost its character as criminal law. But in saying that "it would become absurd to suggest that the statute is intended for a religious purpose", His Lordship is really facing the contention that the legislation is in fact colourable. In this sense, it is not necessary to find that Parliament may never legislate in relation to religion; rather, one merely has to note that the true purpose of the legislation is to affect a modification in labour practices. If so, then the legislation is bad, since it "is trite law that labour relations is within the ambit of legislation of the provincial governments". ${ }^{115}$

In rendering this decision, Riley $\mathrm{J}$. is meeting head-on a contention which, unlike the argument that criminal law has changed since 1903, has been argued at least impliedly in virtually every case involving provincial Sunday legislation. And with this part of the judgment a great number of persons are liable to agree. Certainly a reading of the Ontario Law Reform Commission Report ${ }^{116}$ indicates that the learned Commissioners felt the modern import of the legislation is purely secular, for, if one dissects their recommendations, one discovers that they advocate little more than a change in title to tailor the Lord's Day Act into valid provincial legislation. One might also note that even Mr. Justice Ritchie, who certainly leaned over backwards to support the legislation in Robertson of Rosetanni v. $R .{ }^{117}$ agreed that the true effect of the legislation is secular, and the fact that he did not feel compelled to invalidate the Act on that ground has been severely criticised.118 And if further support is found necessary for Riley J.'s position, it could certainly be in the history of the legislation itself, which is one of the most picturesque examples of an unwilling Parliament submitting to pressure from the provinces. In essence, the Lord's Day Act is provincial legislation enacted under the banner of Parliament, by edict of the Privy Council!

The third argument, advanced in the Boardwalk case, that the statute offends against the Bill of Rights, will be dealt with in the next section.

On appeal to the Appellate Division of the Supreme Court of Alberta, Riley J.'s judgment was reversed.110 Speaking for the court in a short judgment, McDermid J.A. cited the relevant cases holding that the statute was intra vires as part of the criminal law. Offering no sympathy for either side of the controversy, His Lordship bowed out with a gracious respect for stare decisis; "The respondents' arguments can only be dealt with in the Supreme Court of Canada."120 Unfortunately, the Boardwalk never had that opportunity. On December 22, 1972, after a reservation of one month, the court of Fauteaux, C.J.C., Abbott and Pigeon, JJ. declined leave to appeal, giving no reasons whatsoever.

Mr. Justice Riley's judgment will not be easily dismissed by others, for it was never expressly rejected. Indeed, were it not for the respect which the law must

115 Id. at 23.

116 Supra, n. 76.

117 Supra, n. 32.

118 Laskin, supra, n. 34 at 154.

119 Supra, n. 39.

120 Id. at 192. 
show its evolution, little would stand in the way of approval. To this writer, and probably to a great number more, the logic and force of His Lordship's arguments are, while not infallible, a great deal more persuasive than the reasons given by the Privy Council in 1903. One may not agree with the entire decision; in many respects it is not "sound" law. Yet it presents a fresh outlook on an old problem, and it is as thorough as it is courageous. It is completely understandable that the Appellate Division preferred to abstain in the matter; they are entitled and perhaps even compelled to do so. But the Supreme Court, in refusing to even hear arguments which it had never expressly heard before, cannot be so excused. Its silence is an insult to the very learned exposition of the Trial Judge, and what is more important, it is proof positive that the law is not a "living, breathing thing". With the greatest respect, stare decisis was never designed to make us live in the past.

\section{Is The Act Rendered Inoperative by Virtue of the Canadian Bill of Rights?}

The third argument put forth in the Boardwalk case was that the federal Act offends section 1 (b) of the Canadian Bill of Rights. While the majority of Mr. Justice Riley's judgment is rather lucid, his response to this argument, unfortunately, raises the questions but fails to answer them. Presumably, however, His Lordship did not feel under any obligation to come to a conclusion on the point, having already decided that the legislation was initially invalid. The result is that we must rely solely upon the judgments of the Supreme Court in 1963.

Robertson and Rosetanni v. R.121 was one of the first cases to reach the Highest Court in which the infant Bill of Rights ${ }^{122}$ was argued. This Act declares:

1. It is hereby recognized and declared that in Canada there have existed and shall continue to exist without discrimination by reason of race, national origin, colour, religion or sex, the following human rights and fundamental freedoms, namely, . . .

(b) the right of the individual to equality before the law and the protection of the law;

(c) freedom of religion; .....

2. Every law of Canada shall, unless it is expressly declared by an Act of the Parliament of Canada that it shall operate notwithstanding the Canadian Bill of Rights, be so construed and applied as not to abrogate, abridge or infringe or to authorize the abrogation, abridgment or infringement of any of the rights or freedoms herein recognized and declared, ....

5. (2) The expression Taw of Canada' in Part I means an Act of the Parliament of Canada enacted before or after the coming into force of this Act, any order, rule or regulation thereunder, and any law in force in Canada or in any part of Canada at the commencement of this Act that is subject to be repealed, abolished or altered by the Parliament of Canada.

The majority of the five-man court, speaking through Ritchie J., held that "freedom of religion" as defined in the Bill of Rights was not in any way abridged or infringed by the Lord's Day Act. Cartwright J. (as he then was) dissented, stating, "that this is an infringement of religious freedom I do not doubt". ${ }^{123} \mathrm{He}$ then went on to find that the Bill of Rights must prevail in any situation in which there is an irreconcilable conflict between it and another Act of Parliament.

The majority opinion has been severely criticised ${ }^{124}$ both in its reasoning and its conclusion. With regard to the former, Prof. Laskin (as he then was) characterizes Ritchie J.'s reasoning as "begin[ning] with his rather questionable assertion", ${ }^{125}$ "not calculated to inspire much confidence in the depth analysis

121 Supra, n. 32.

122 Supra, n. 33.

123 Robertson \& Rosetanni v. R., supra, n. 32 at 660 .

124 See Laskin, supra, n. 34.

125 Id. at 151 . 
of the issues", 126 "begs the question", ${ }^{127}$ and "circular reasoning which assumes the very point it purports to make". ${ }^{128}$ With regard to the latter, probably more important, conclusion of the case Laskin comments: ${ }^{129}$

The majority at once accepts the application of the Bill of Rights in general and rejects it in the particular, and in so doing invites the charge that either it has enmeshed itself in a constitutional contradiction or has reached a conclusion that robs freedom of religion of substance, both in its constitutional import and in its expression in the Bill of Rights.

There are indeed various aspects of the majority decision which leave the civil libertarian wondering whether the Bill of Rights means anything at all. While it is probable that the majority would have followed Cartwright $\mathrm{J}$. in invalidating the Act if it conflicted with freedom of religion, ${ }^{130}$ the narrow scope afforded that concept leaves little to be in conflict with.

The majority judgment can be divided into two arguments, and it will be convenient to look at it in that fashion. The first is founded on the opening words of the Bill of Rights which state: "It is hereby recognized and declared that in Canada there have existed and shall continue to exist .... the following human rights and fundamental freedoms ...." (emphasis added) Ritchie J. cites from Chaput v. Romain"181 to the effect that "All religions are on an equal footing, and Catholics, as well as Protestants, Jews, and other adherents to various religious denominations, enjoy the most complete liberty of thought ..." and from Saumur v. The City of Quebec ${ }^{132}$ as follows:

From 1760, therefore, to the present moment religious freedom has, in our legal system, been recognized as a principle of fundamental character; and although we have nothing in the nature of an established church, that the untrammelled affirmations of 'religious belief' and its propagation, personal or institutional, remain as of the greatest constitutional significance throughout the Dominion is unquestionable.

Laskin states in his comment: ${ }^{193}$

Although Rand J. was concerned with constitutional power in respect of the political freedoms, this was only in the negative sense of determining whether, if the by-law concerned freedom of speech or of religion, it was within or outside of provincial competence to authorize it. He was no more concerned to explore the full meaning of freedom of religion in Saumur than was Taschereau J. in Chaput v. Romain.

Nonetheless, on the basis of two snippets, torn from their contexts, Ritchie J. felt he could conclude (in his words) that it is apparent from these judgments that "complete liberty of religious thought and 'the untrammelled affirmation of religious belief and its propagation, personal or institutional were recognized by this Court as existing in Canada before the Bill of Rights and notwithstanding the provisions of the Lord's Day Act". [(1963) 41 D.L.R. (2d) 485 at 492$]$ With respect, the two passages culled from the two judgments do not in any way lead to such a conclusion.

This writer could neither state his criticism more eloquently than that learned author has done, nor agree with him more. With respect, Ritchie J.'s argument

126 Id. at 152.

127 Id. at 153.

128 Id. at 155.

$129 \mathrm{Id}$. at 148.

180 Fauteux and Ritchie JJ. were both with the majority in The Queen v. Drybones, supra, n. 36. As Laskin points out in his article, supra, n. 34 at 149 , the majority "could have escaped from what I believe is the dilemma of its actual judgment by holding that in case of conflict between the Lord's Day Act and the Bill of Rights the latter must give way; .. . The fact that the majority courageously eschewed this escape meant that its alternatives were to find that the Lord's Day Act was not concerned with freedom of religion in general or, even if it was, that it did not offend against freedom of religion as expressed in the Bill of Rights."

181 [1955] S.C.R. 834, referred to by Ritchie J. in Robertson and Rosetanni v. R., supra, n. 32 at 655 .

132 [1953] 2 S.C.R. 299, referred to by Ritchie J. in Robertson and Rosetanni v. $R$., supra, $\mathrm{n} .32$ at 655.

${ }^{133}$ Laskin, supra, n. 34 at 152-153. 
comes down to nothing more than this: Parliament has declared in the Bill of Rights that certain fundamental freedoms have existed and do exist in Canada. "Freedom of religion", as expressed in the Bill, must be that freedom which existed, not in any abstract sense, but in the law of Canada immediately prior to the passage of the Bill. Prior cases, in which "freedom of religion" was found to exist, were decided by courts with full knowledge of the outstanding provisions of the Lord's Day Act. Ergo, the Lord's Day Act does not violate the kind of religious freedom protected by the Bill. To put the matter in a more comprehensible state, the "fundamental freedoms" protected by the Bill are only those which remain consistent with the statute law of Canada in force as of 1960.

The syllogism is appealing, but, while Ritchie J. is quick to point out that the Bill of Rights declares the freedoms to have existed already, he is seemingly unconcerned that the Bill of Rights is, by s. 5, aimed, inter alia, at already existing legislation. If the fundamental freedoms referred to in the Bill were in no way abrogated or infringed by existing legislation, why did s. 5 speak of "any law in force in Canada or in any part of Canada at the commencement of this Act"? Are we to infer, as Ritchie J. would suggest, that s. 5 is meaningless? It is submitted that the better view is that Parliament fully realized, indeed welcomed, that some existing legislation would fall in the face of fundamental freedoms that had already existed, not from Confederation, but from the dawn of society. Parliament fully recognized that existing legislation might abrogate or infringe those freedoms, just as it realized that future legislation, unless carefully scrutinized by the Minister of Justice, ${ }^{134}$ might do so. It was precisely this mischief which the legislation was designed to correct.

It should also be pointed out that either Ritchie J. did not mean what he said in 1963, or he had changed his position by 1970. In The Queen v. Drybones ${ }^{135}$ His Lordship expressly countered the argument advanced by the Crown, based on his own judgment in 1963, that freedom of religion, as used in the Bill of Rights, must mean freedom of religion subject to the provisions of the Lord's Day Act. Ritchie J. gave his own interpretation of what he said in Robertson \& Rosetanni; freedom of religion must have a similar meaning in both the Bill of Rights and the prior cases and the definition which he gathered from the cases was one not in any conflict with the Lord's Day Act. With respect, the distinction between these two views is too subtle for this writer. Does it really matter whether one refers to the Lord's Day Act before or after the drafting of the definition of freedom of religion? In either circumstance, the Bill of Rights cannot operate as a direct result of the prior existence of the Act; for in the one case the only freedom protected is that which is subject to the Act, while in the other case all "freedom" is protected, but "freedom" is defined as that which existed at the passage of the Bill, a definition which is necessarily modified by the theretofore valid existence of the Act. Either way, of course, "freedom of religion" is, as Laskin put it, "writ small". It is interesting to note, somewhat paradoxically, that this confinement was assisted by prior judicial attempts to give a much broader meaning to the phrase. Both the extract from Chaput v. Romain and the one from Saumur, quoted by Ritchie J., were in this vein. Yet it would seem that the more the courts spoke of widening the definition before the Bill, with the Lord's Day Act outstanding, the greater was the fuel for narrowing it once the Bill was proclaimed.

The second argument put forth by the majority, in support of its decision, rested on a distinction drawn between the purpose and effect of the legislation. It was conceded, indeed stressed, that the purpose of the legislation was that of

134 Bill of Rights, supra, n. 33 at s. 3.

195 Supra, n. 36. 
"preserving the sanctity of Sunday". ${ }^{130}$ To find that the purpose was otherwise would deprive the legislation of its constitutional foundation. Ritchie J. went on, however, to declare that notwithstanding the religious purpose, the effect of the legislation was "purely secular". ${ }^{137}$ Such a determination was necessary to circumvent the argument that Jews, who believe Saturday is the Sabbath, were discriminated against by the Act and, thus, denied equal protection of the laws as guaranteed by s. 1 (b) of the Bill of Rights. It is to be remembered that the foregoing determination that the Act was valid was in reference to s. 1(c), "freedom of religion" and, thus, offered no defence to an argument brought under s. 1(b). Furthermore, Ritchie J. could draw little comfort from his previous citation from Chaput v. Romain that "All religions are on an equal footing. . . ."

Laskin, in criticising this distinction between purpose and effect, ${ }^{138}$ first notes that the current of constitutional cases is against the distinction, or that where it is drawn, it comes down on the side of purpose, which, in this case, would render the legislation in conflict with the Bill. But even if there is such a distinction in theory, Laskin opines that it is negligible in the instant case: ${ }^{139}$

If the purpose (or object) of the Lord's Day Act was to promote sanctity of Sunday, was this not also the effect of the legislation in so far as unbelievers in Sunday as a holy day were compelled to treat it as if it were? . . . the purpose being what it was, there is some difficulty in saying that the effect was any different when regard is had to the nature of the legislation.

One becomes even more skeptical of Ritchie J.'s reasoning when his analysis of the effect of the legislation is revealed: ${ }^{140}$

The practical result of this law on those whose religion requires them to observe a day of rest other than Sunday, is a purely secular and financial one in that they are required to refrain from carrying on or conducting their business on Sunday as well as their own day of rest. In some cases this is no doubt a business inconvenience, but it is neither an abrogation nor an abridgment nor an infringement of religious freedom ....

One can only imagine what equality means to $\mathrm{Mr}$. Justice Ritchie! Can it be said that no legislation deprives a man of equality before the law merely because its effect is "purely secular and financial"? Would a law which makes beggars of Jews and millionaires of Christians be safe from the Bill of Rights? Would a law which imposed a tax upon Jewish Synagogues but not Christian Churches not be discriminatory? It is submitted that a law which has a "purely secular and financial" result "in that they are required to refrain from carrying on or conducting their business on Sunday as well as on their own day of rest" differs from these very little, if at all.

Mr. Justice Cartwright, as he then was, dissented from the majority in Robertson \& Rosetanni. He agreed that the purpose of the Lord's Day Act was to "compel, under the penal sanctions of the Criminal Law, the observance of Sunday as a religious holy day by all the inhabitants of Canada".141 But he also felt that that was the effect of the legislation. Moreover, he did not so restrict his definition of freedom of religion as did the majority: ${ }^{142}$

In my opinion, a law which compels a course of conduct, whether positive or negative, for a purely religious purpose infringes the freedom of religion.

A law which, on solely religious grounds, forbids the pursuit on Sunday of an otherwise lawful activity differs in degree, perhaps, but not in kind from a law which commands a purely religious course of conduct on that day, such as for example, the attendance at least once at divine service in a specified church.

136 Robertson and Rosetanni v. R., supra, n. 32 at 658.

137 Id. at 657.

138 Supra, n. 34 at $154-155$.

139 Id.

140 Robertson \& Rosetanni v. R., supra, n. 32 at 657-658.

$111 \mathrm{Id}$. at 660 .

142 Id. 
Cartwright J.'s task, however, was not complete upon this finding. There still remained the difficult question of how to interpret s. 2 of the Bill of Rights. In Regina v. Gonzales, ${ }^{143}$ Davey J.A., of the British Columbia Court of Appeal, had held the year before that:14

The section does not repeal such legislation either expressly or by implication. On the contrary, it expressly recognizes the continued existence of such legislation, but provides that it shall be construed and applied so as not to derogate from those rights and freedoms. By that it seems merely to provide a canon or rule of interpretation for such legislation. . . If the prior legislation cannot be so construed and applied sensibly, then the effect of s. 2 is exhausted, and the prior legislation must prevail according to its plain meaning.

\section{Cartwright J. did not agree: ${ }^{14 s}$}

The imperative words of s. 2 of the Canadian Bill of Rights, quoted above, appear to me to require the courts to refuse to apply any law, coming within the legislative authority of Parliament, which infringes freedom of religion unless it is expressly declared by an Act of Parliament that the law which does so infringe shall operate notwithstanding the Canadian Bill of Rights. . . . In my opinion where there is an irreconcilable conflict between another Act of Parliament and the Canadian Bill of Rights the latter must prevail.

This view of the operation of the Bill of Rights was later adopted by a majority of the Supreme Court in Regina v. Drybones ${ }^{148}$ where, interestingly enough, Cartwright, C.J.C., joined by Abbott and Pigeon JJ., openly reversed his position and held that Davey J.A. was correct after all. Fauteaux and Ritchie JJ., both in the majority in Robertson \& Rosetanni, were also in the majority in Drybones, leading to the conclusion that had they found the Bill of Rights to conflict with the Lord's Day Act, they would have joined Cartwright $\mathrm{J}$. in holding the latter invalid.

As an aside, it is submitted that even if s. 2 of the Bill of Rights is nothing more than a canon of construction, its effect is not completely nugatory. If the real purpose of the Lord's Day Act is to keep the sanctity of the Sabbath, then, presumably, the Bill of Rights can be used, as a canon of construction, to hold that the definition of "Lord's Day" in s. 2(b) of the Act is not exhaustive. If, for example, a Jew can show that he bona fide celebrates the Lord's Day on Saturday, not Sunday, and if there really is freedom of religion in Canada and "nothing in the nature of an established church,"147 then a court ought to be able to hold that he does not violate the Act, so long as he refrains from work on his Lord's Day. The success of such an argument would depend upon the willingness of the court to proceed in the face of the wording of $s .2(b)$ of the Act. Yet to fail to do so and prosecute this Jew who observes what he considers, quite justifiably, to be the Lord's Day would be to fail to construe the Act so as not to abrogate the Jew's equal protection of the law and (possibly) his freedom of religion. Moreover, not only would these freedoms be seen as illusory, but the purpose and spirit of the Act, which has already been held to have been passed for the purpose of sanctifying the Lord's Day, would be defeated. It is submitted that a court is perfectly justified today in interpreting the definition of 'Lord's Day" given in the Act, as merely an example given by Parliament and in no way a direction by it, that, for a Jew, the Lord's Day is other than Saturday or, for a Moslem, it is other than Friday.

It is noted above that the third point argued in the Boardwalk case was that the Lord's Day Act offends s. I(b) of the Bill of Rights. There was no argument that freedom of religion was offended, merely equal protection, and this is not

148 (1962) 132 C.C.C. 237.

$144 I d$. at 239.

145 Robertson and Rosetanni v. R., supra, n. 32 at 662.

146 Supra, n. 135.

117 Saumur v. The City of Quebec, supra, n. 110 at 327. 
surprising in light of the relative strength of the arguments cited by Ritchie J. Mr. Justice Riley pointed to the questions involved, but never came to a conclusion on the matter. He first noted that there was doubt as to where legislative power with respect to religious freedom lies, citing the diversity of opinions in Saumur. He then noted the appellant's arguments and indicated that the effect of the Bill of Rights was not clearly decided by Robertson and Rosetanni. He refused to go further than this, however, since he had already found that the Act was ultra vires. The only conclusion that this writer can suggest is that His Lordship did not feel ready to deal with the Bill of Rights question but wished to preserve the appellants' arguments on the record. If this be the case then he too must have been disappointed with the ultimate disposition on appeal.

In one sense it is not surprising that the Supreme Court refused leave when one remembers that the court consisted of Fauteux C.J.C., Abbott and Pigeon JJ. Fauteux C.J.C. and Abbott J. were both with the majority in Robertson and Rosetanni, finding that the Act did not conflict with freedom of religion. Pigeon and Abbott JJ. both dissented in Drybones. So one can perhaps understand that they were not sympathetic to any of the arguments.

\section{Comparison with the United States}

This is a paper on the subject of the Canadian law of Sunday observance. It is all too easy, especially in fields touching upon the civil rights and liberties of individuals, to draw heavily from south of the 49th Parallel. Indeed, many of us might prefer the way in which those courts have handled these matters. But in keeping with recent trends toward nationalism throughout our Society, and quite frankly for the sake of brevity, it is not intended here to explore the depths of the American experience. Were we to do so, it is as likely as not a journey from which we would not escape, for few subjects have such a long, colourful, and even at times bitter history. ${ }^{148}$

Reference must be had, however, to the four decisions of the United States Supreme Court heard together in 1961. ${ }^{240}$ In these cases the court was asked to set aside the legislation on precisely the same grounds argued in the Canadian court in Robertson and Rosetanni, namely that the legislation violated religious freedom. It must be remembered that in the United States such an argument, owing to the constitutional safeguards, is infinitely more persuasive; yet, it met with precisely the same fate. The majority of the court, especially Chief Justice Warren and Mr. Justice Frankfurter, found that although the legislation showed a long history of religious domination it had become completely secular in both purpose and effect. Any impact of a religious nature was merely incidental, and imposed no direct burden of religious observation. Mr. Justice Douglas, in a forceful dissent, had no trouble whatever in finding a violation of the free exercise of religion and an "unconstitutional implication of the states in religious matters". ${ }^{150}$

It is immediately apparent that the "purpose and effect" argument used by both Supreme Courts is the same in character, though completely opposite in conclusion as to purpose: ${ }^{151}$

Judicial analysis in both countries rejects an interpretation conceding religious motivation

for Sunday legislation at the precise point at which acceptance would require invalidation

${ }^{148}$ For a fine account of both the social and legal history of Sunday legislation in the United States, see Johns, Dateline Sunday, U.S.A. (1967). As a wise professor once told his class, "it is painless history".

149 McGowan v. Maryland (1961) 366 U.S. 420; Two Guys from Harrison v. McGinley (1961) 366 U.S. 582; Gallagher v. Crown Kosher Super Market (1961) 366 U.S. 617; Braunfield v. Brown (1961) 366 U.S. 599.

150 McGowan v. Maryland, supra, n. 149 at 579.

181 Barrons, Sunday in North America, (1965) 79 Harv. Law Rev. 42 at 54. 
of the legislation. In Canada we are told purpose and effect must be distinguished. The purpose of the Lord's Day Act is concededly religious, but we are assured the effect is entirely secular. In the United States, rejection of a theory of religious motivation begins at an earlier stage and both purpose and effect are held to be predominantly secular. The similarity in result reached suggests that the prevailing judicial tests for measuring whether Sunday legislation offends religious freedom are rather clearly expeditious.

Disparities in legal doctrine, it appears, are trivial in comparison to the overriding realities of social fact; and the dominant social fact is apparently that Sunday laws are a desired breed of legislation on this continent, with the two Supreme Courts being responsive to that reality.

\section{THE CONSTITUTIONAL VALIDITY OF PROVINCIAL LEGISLATION}

For many years after 1867 it was apparently assumed on all hands that the power of legislating with reference to Sunday observance within a Canadian Province was by s. 92 of the Act exclusively committed to the Provincial Legislature as being either a matter relating to property and civil rights in the Province or as being one of a merely local or private nature in the Province .... So widely held was this view that not only was no Dominion statute with reference to this subject ever promulgated, but in most of the Provinces legislation was passed having for its object the compulsory observance of Sunday within the Province or the laying down of rules of conduct to be followed on that day, accompanied by appropriate sanctions for non-observance or breach.152

In 1903, the Privy Council put an end to provincial Sunday observance statutes when it declared such legislation was ultra vires in the Hamilton Street Ry. Co. case. Notwithstanding that the province of Ontario considered its Lord's Day Act $^{153}$ to be valid legislation respecting Civil Rights (92(13)) and of a merely local nature (92(16) ), the Judicial Committee ruled that offences against the Sabbath were part of the common law at Confederation and thus formed a part of the criminal law reserved to Parliament. Since then, numerous cases have come before the courts alleging that a particular provincial statute is in respect of the preservation of the sanctity of the Sabbath and is thus ultra vires. The questions which were discussed, and to some degree left unanswered, included: How is the religious purpose of a provincial enactment to be determined? Is the provincial incapacity confined to the profanation of the Sabbath, or is it beyond the power of a province to pass legislation in relation to religion generally? Does a province have the power to pass secular, as distinct from religious, Sunday legislation?

At the outset it is to be noted that not all provincial legislation in relation to the Lord's Day is invalid. The cases hold ${ }^{154}$ that legislation permissive in character, and not prohibitive, is intra vires. There are two branches to this rule; firstly, the legislation in question must be initially valid - i.e., within the power of the province under section 92 of the B.N.A.Act. Secondly, the legislation must not prohibit any activity which was by the common law or the Criminal Code ${ }^{155}$ declared to be a crime. The validity of such legislation can be said to derive from the phrase contained in ss. 4, 6 and 7 of the Lord's Day Act;

It is not lawful for any person on the Lord's Day, except as provided herein, or in any provincial Act or law now or hereafter in force, .... . (emphasis added)

152 Lord's Day Alliance of Canada v. A.-G. for Man., supra, n. 23.

153 R.S.O. 1897 , c. 246.

154 Lord's Day Alliance of Can. v. A.-G. for Man., supra, n. 23; Lord's Day Alliance of Can. v. A.-G. for B.C., supra, n. 53; Ouimet v. Bazin (1912) 3 D.L.R. 593.

155 The rule as originally promulgated in Lord's Day Alliance of Canada v. A.-G. for Man., supra, n. 23, was that the provincial statute must not reflect the criminal law as it appeared in the English common law in force in the province. In that case, the court found that Sunday excursions were not so prohibited. In Lord's Day Alliance of Can. v. A.-G. for B.C., supra, n. 53, however, the legislation in question involved the holding of sports on Sunday, an activity which was prohibited by the statutes in force in the province. The court noted that $s .8$ of the Criminal Code had abolished common law offences, and as sports were not outlawed in the Code, and as the only other prohibition was to be found in the Lord's Day Act, the province could properly enact permissive legislation in that field without seeming to repeal a crime. 
If the legislation meets the first branch of the rule stated above, it may be considered a "provincial Act or law now or hereafter in force". With regard to the second branch, if the legislation is prohibitive it would be an attempt by the province to repeat or otherwise engage in the field of criminal law, provided the subject was one which fell within that definition. Traditional doctrine would suggest that it is the act of legislating in relation to a subject, and not its prohibitive or permissive character, which deprives legislation of its validity. Yet here we see a somewhat dubious distinction being drawn which would appear to give the provinces a partial jurisdiction which they would not otherwise have. However, the courts have held that this is not in any way a delegation of power: ${ }^{150}$

The idea of delegation arises from a misconception of the operation of $s$. 6 . The legislative efficacy in prohibiting the activity named is that solely of Parliament; the effect of the exception is to declare that in the presence of a provincial enactment of the appropriate character the scope of $s$. 6 automatically ceases to extend to the provincial area covered by that enactment. The latter is a condition of fact in relation to which Parliament itself has provided a limitation for its own legislative act. That Parliament can so limit the operation of its own legislation and that it may do so upon any such event or condition is not open to serious debate.

While the above reasoning seems sound, there is nonetheless a strange sensation that the difference between waiver of paramountcy and delegation of legislative authority is slight. Though perhaps only permissive in character, provincial legislation of this sort does in fact de-criminalize certain activity otherwise criminalized by the Act. The logical conclusion of this reasoning is that Parliament could de facto leave virtually the entire field of criminal law in the hands of the provinces by merely adding to the Criminal Code a section to the effect that no conduct herein proscribed is an offence if otherwise permitted by any provincial Act or law now or hereafter in force. It is submitted that Riley J. was aware of this interpretation when he struck down the Lord's Day Act in the Boardwalk case.

The cases show quite clearly that where the purpose of provincial legislation is to guard against the profanation of the Sabbath the legislation is invalid even if it appears to be regulatory legislation within s. $92 .{ }^{157}$ Nor is there any magic in the singling out of Sunday, for legislation compelling the observance of "feast" (holy) days is also invalid. ${ }^{158}$ Yet, many cases indicate that the provinces may validly legislate in respect of retail closing, including Sunday, ${ }^{150}$ and in two cases; these valid closing laws applied only to Sundays. ${ }^{100}$ Moreover, since Hodge v. The Queen, it seems to have been accepted that the closing of $a$ tavern on Sundays is within the provincial regulatory power. Indeed, the Ontario Report, which is in all areas an extensive document, nowhere discusses the Liquor Licensing statutes, thereby indicating that they are not to be construed as Sunday observance legislation. Where do we draw the line between Sunday observance legislation, which is invalid, and Sunday closing legislation,

166 Lord's Day Alliance of Can. v. A.-G. for B.C., supra, n. 53 at 509-510.

157 A.-G. for Ontario v. Hamilton Street Ry. Co., supra, n. 16; Re Legislation Respecting Abstention from Labour on Sunday, supra, n. 17; Ouimet v. Bazin, supra, n. 154; Parish of St. Prosper v. Roderigue, supra, n. 22.

108 Henry Birks \& Sons v. City of Montreal, supra, n. 27.

100 R. v. Southern Garage (1959) Ltd. (1963) 39 D.L.R. (2d) 408; Henderson Thriftway Petroleum Ltd. v. Reeves (1956) 3 D.L.R. (2d) 507; R. v. Bachynski [1938] 2 D.L.R. 691; R. v. Epstein [1931] O.R. 726; O'Brien v. Royal George (1921) 57 D.L.R. 301; but cf., Parish of St. Prosper v. Rodrique, supra, n. 22; R. v. Waldon (1914) 18 D.L.R. 109; R. v. Slowin [1923] i W.W.R. 252; Clark v. Wawken [1930] 2 D.L.R. 596; Connaught Park Jockey Club v. District Magistrates Court and Township of South Hull (1965) 51 D.L.R. (2d) 559; La Ville de Montreal v. La Salle de Danse "Dans le vent" [1965] R.L. 365.

${ }^{100}$ Re Gregory and City of Hamilton [1942] 4 D.L.R. 735; Re Karry and City of Chatham (1910) 21 O.L.R. 566. 
which is valid? In the Hamilton Street $R y$. Co. case the Privy Council refused to decide the point but noted its agreement with Hodge v. The Queen. Little light was shed on this question until Lieberman v. The Queen, ${ }^{101}$ a judgment of the Supreme Court of Canada in 1963. In that case the accused was charged with operating a bowling alley on Sunday, contrary to a by-law of the municipality of St. John which prohibited the opening of a bowling alley between 12:00 and 6:00 every weekmight, "or on Sunday". It was argued that the by-law was invalid on the ground of a conflict with the Lord's Day Act. Mr. Justice Ritchie held that the by-law was valid:162

The prohibition against keeping public billiard rooms, pool rooms and bowling alleys open during the hours specified in $s$. 3 is not to be read in isolation from the rest of the by-law and when the enactment is read as a whole it will be seen that the impugned section is but one of a number of regulations which the common council has imposed upon the operators of such businesses in the city of Saint John. The nature of the restrictions so imposed by the common council appears to me to reflect nothing more than the opinion of that body as to the manner in which such businesses are to be carried on for the better government of the city.

It is not to be lightly assumed that any part of the by-law is directed to a purpose beyond the legislative competence of the enacting authority and I do not think that the inclusion of Sunday in the hours of closing of these businesses necessarily carries with it any moral or religious significance. ... [His Lordship then examined the various cases which had held provincial legislation in relation to Sunday invalid] . . . It seems to me that these decisions, dealing as they do with statutes the very language of which invites the conclusion that they were intended for the purpose of enforcing the observance of the religious significance attaching to the Sabbath and to other religious feasts, can have no application to the by-law now under consideration, the attack upon which is limited to the fact that the words 'or on Sunday' have been added to a list of other times when certain businesses are to be closed. ... [this by-law] has for its true object, purpose, nature or character, the regulation of the hours at which businesses of special classes shall close in a particular locality in the Province of New Brunswick which is a matter of a merely private nature in that province.

Mr. Justice Ritchie had occasion to speak again on the subject that year when he delivered the majority judgment in Robertson \& Rosetanni: ${ }^{108}$

Different considerations, of course, apply to the power to legislate for the purely secular purpose of regulating hours of labour which, except as to the regulation of the hours of labour of Dominion servants, is primarily vested in the provincial legislatures.

It would seem from the above that the tests for the validity of provincial Sunday closing legislation is nothing more than the simple "aspect test" so well known to students of constitutional law. If the legislation in its "pith and substance" relates to a subject matter within the competence of the province, it is not invalid merely because it also affects the observance of Sunday. The key, of course, is that Sunday is observed for a secular, and not a religious purpose, a determination which has often been quite difficult. Yet satisfaction should be drawn from the conclusion that this difficulty is apparently one of fact, not law.

The invalidity of provincial Sunday observance legislation is sometimes said to be founded upon the principle that the provinces are incompetent to legislate in relation to religion. ${ }^{164}$ Regardless of the merit of this argument, it would appear to be inapplicable where the true purpose of the legislation is to regulate matters falling within s. 92 of the B.N.A. Act and the only religious aspect is one incidental to that purpose. Mr. Justice Rand, who has as great a claim to the former contention as anyone, accepted the latter in Saumur v. City of Quebec: ${ }^{105}$

161 Supra, n. 31.

162 Id. at 647-648.

163 Supra, n. 32 at 657.

164 E.g., per Kellock J. in Henry Birks \& Sons Ltd. v. City of Montreal, supra, n. 27 at 823.

165 [1953] 2 S.C.R. 299 at 333. 
Conceding, as in the Alberta Reference, that aspects of the activities of religion and free speech may be affected by provincial legislation, such legislation, as in all other fields, must be sufficiently definite and precise to indicate its subject matter.

It is apparent that the provinces may, for the purposes of an otherwise valid and secular, regulatory framework, enact legislation which will indirectly compel the observance of Sunday. It is also apparent that the provinces may, until Parliament indicates to the contrary, enact permissive legislation which has for its purpose the non-observance of Sunday. The only question which then remains unanswered by any of the cases is whether the provinces may enact plenary Sunday legislation, not for the purposes of religious observance, but to provide a uniform day of rest. For the Ontario Law Reform Commissioners, this was the penultimate question. Their decision is a resounding "Yes!" With respect, the writer can come forth with little more than a meek "maybe".

The Ontario Law Reform Commission clearly desired Sunday observance legislation. ${ }^{106}$ Moreover, it desired to strip the legislation of its unsavoury religious tenor and at the same time bring back control to the Province. It is not surprising, therefore, that it sought legal validity to do so. Yet it must be a source of embarrassment to the Commission that in an extensive document covering some $\mathbf{4 5 0}$ pages, it relied upon a single paragraph to express its most important determination: ${ }^{167}$

On the basis of the law as we have construed it, it is our opinion that a province can legislate a plenary secular scheme respecting Sundays, and that this legislation can take a prohibitive as well as permissive form as long as it is carefully drawn to achieve secular and not religious objectives. This legislation can be enforced by means of penalties and fines through the province taking advantage of head (15) of section 92 of the B.N.A. Act.

The Report goes on to discuss the possible problem of an overlapping of powers if the new provincial Act should come into conflict with the Lord's Day Act, but is otherwise virtually silent on the bold conjecture it has just put forth! This writer has no doubt that such legislation would be breaking new ground if ever accepted by a Canadian court.

One must bear in mind that the Act proposed by the Commission would differ very little from the legislation successfully defeated in the Hamilton Street Ry. Co., Ouimet v. Bazin and Parish of St. Prosper v. Roderigue cases. What makes the Commissioners so sure that the courts will not adhere to their former decisions? Two possible reasons may be given. In the first place, the Commissioners recommend a change in the title of the legislation," as a means of reflecting its secular purpose and effect". ${ }^{168}$ Less obviously colourable devices have been unsuccessful in the past. The second reason is perhaps more worthy of note. It was found in the earlier cases that the "true purpose" of the legislation was in respect of religion. Strong arguments can be put forth that the modern legislation, despite its religious beginnings, is and should be in relation to labour relations and is thus secular today. Such an argument has the support of the United States Supreme Court. ${ }^{200}$ Yet the Supreme Court of Canada found to the contrary in Robertson and Rosetanni. An even more recent indication of the courts' present attitude is found in their refusal to hear the appeal in the Boardwalk case, where the very argument was made. It is submitted that the history of Sunday observance legislation is too great a burden for the Commissioners to unload with merely careful legislation "drawn to achieve secular and not religious objectives".

${ }^{166}$ See Ontario Law Reform Commission Report, supra, n. 76, recommendations $1-5$ at 371.

167 Id. at 286.

168 Id. at 273.

169 Supra, n. 149. 
Even if the courts were to accept the initial validity of this proposed legislation, it is not at all certain that they would follow the reasoning of the Commission as to the effect of a conflict with the Lord's Day Act. The Report states: ${ }^{170}$

Normally, if there is a conflict between federal and provincial laws in a concurrent area,
then federal paramountcy obtains and the federal legislation takes effect with the
inconsistent provincial legislation becoming suspended. However, if the provincial
Sunday legislation merely supplements the federal Lord's Day Act or duplicates it as
part of a broader secular scheme, then the federal and provincial Sunday legislation can
live together, each having entered the field through separate constitutional 'gates of
entry'.

This is doubtless so. However, one is driven to question just what this "broader secular theme" would be. If the new Act is merely to be a re-introduction of the Lord's Day Act under a secular guise, and the rest of the Report indicates little to the contrary, then it might be "secular", but it is hardly "broader".

For advocates of Sunday legislation, the result is a constitutional nightmare. So long as the legislation retains its present framework, it will by force of precedent, be beyond the reach of the provinces. Yet if it remains under federal supervision, it will, by necessity, retain its unsavoury religious tenor.

The foregoing analysis should not be taken to be in any way a repudiation of the basic philosophy of the Ontario Report that future Sunday observance legislation, if we are to have any at all, should reflect the prevailing social requirement that such legislation be secular in nature. Nor does the writer have any particular animosity toward control of the legislation being in the hands of the provinces, though it is hoped that the law could achieve some uniformity across the country. But neither of these objectives, involving as they do the reversal of centuries of law, can be accomplished overnight, nor with bold assertions and baseless conjecture.

\section{Self-imposed Provincial Incapacity}

No consideration of the constitutional validity of provincial Sunday legislation would be complete without a moment's reflection on the recently enacted Alberta Bill of Rights. ${ }^{171}$ It is to be remembered that this Act approximates the Canadian Bill of Rights and hence the discussion elsewhere in this paper in relation to its effect on federal legislation should be applicable. However, it is to be noted that since any provincial legislation will be founded on secular, rather than religious grounds, it is less likely that "freedom of religion" would be argued as strenuously or often as "equal protection of the laws". Also, since the proposed provincial legislation would not pre-date the Bill of Rights, the latter would be less susceptible to the kind of interpretation offered by Ritchie J., in Robertson \& Rosetanni.

In Walter v. Attorney General of Alberta, ${ }^{172}$ the Supreme Court of Canada upheld the validity of the Alberta Communal Property Act. ${ }^{173}$ Martland J., in delivering the judgment of the court, held that the Act was not in relation to religion. The Government of the Province obviously had doubts about this conclusion, for it repealed the Act. The stated reason was that it would conflict with the new Bill of Rights. It is reasonable to believe that this same government would, $a$ fortiori, refuse to pass the kind of legislation envisaged by the Ontario Law Reform Commission.

170 Supra, n. 76 at 287.

171 S.A. 1972 , c. 1.

172 [1969] S.C.R. 383.

178 R.S.A. 1970 , c. 59. 


\section{SUNDAY LAWS: RELIGIOUS SAFEGUARD, LABOUR STANDARD, OR ANACHRONISM?}

This paper has surveyed the history, interpretation and validity of state proscriptions on Sunday activity. It remains to determine whether we want them to continue.

\section{Religious Freedom}

The Canadian courts have quite rightly found that a major purpose of "blue" laws has always been to preserve the sanctity of the Christian Sabbath. The civil libertarian must question, however, whether these courts have properly accounted for two fundamental canons of our Canadian social intercourse, if not our law: the state's abstention from any favouritism of any set of religious beliefs over another or at all, and the right of each individual to worship in his own manner without discrimination, hardship or intimidation. The two go hand-inhand. If the state should establish any religion, it works a discrimination against the individual and vice-versa. Therefore, it is totally irrelevant to speak of Canada enjoying the one without the other.

Only the Sophist would truly believe that "purely economic and financial" consequences are not discriminatory. In our society, what are better indicators of hardship? Would we say the negro is not discriminated against because he is forced to live in the ghetto while "whitey" lives in the suburbs? Or is the only manifestation of discrimination the humiliation of riding at the back of the bus?

Nor will the political realist be fond of arguing that Canada is a "Christian country". Our heritage is Christian. Most of our population is Christian. But so too is our heritage English. Most of our population is English. Are we English? There is a dominant heritage of liberalism in Canada. The present Canadian Government is Liberal. Is this a liberal Country? These are not idle questions, for there is little which a label can convey without being misleading. The fact is that this country professes, and desires, to place all religions on an equal footing. Parliament has said as much in the Canadian Bill of Rights. If our law does not reflect this, then it does a disservice to the values and lives that have made this country strong, free and tolerant.

Sunday laws work two injustices: firstly, they deprive the individual of freedom of thought and his full measure of society's bounty. They subject minority faiths to economic hardship and often intimidate them into abandoning their own tenets in an effort to mitigate their loss. They influence the agnostic unfairly. And they perpetuate the hostility and contempt which have so often in the past led to further discrimination and suffering. Secondly, these laws deprive society of a good measure of its civilisation. They present an aura of repression and hypocricy. And for each citizen they discriminate against, there is a corresponding loss to all. As Cartwright J., said: ${ }^{174}$

A law providing that every person in Canada should, on pain of fine or imprisonment, attend divine service in an Anglican church on at least one Sunday in every month would, in my opinion, infringe the religious freedom of every Anglican as well as that of every other citizen.

Frankfurter J.'s famous statement, "freedom from conformity to religious dogma, not freedom from conformity to law because of religious dogma"175 has been interpreted in many ways. Yet, it would seem that each time it has been referred to, the emphasis has been on the latter phrase, and the former has been ignored. We are not now in a situation where some individual or group is wishing to argue its scruples as a defence to the law. Rather, we are concerned with the extent to which the law can and should demand "conformity to religious dogma".

174 Robertson \& Rosetanni v. R., supra, n. 32 at 661.

176 Board of Education v. Barnette (1943) 319 U.S. 624 at 653. 
To the extent that any sector of the Canadian public does not believe in Sunday as the Sabbath or does not believe it must be sanctified, the Lord's Day Act compels, under criminal penalty, conformity to religious dogma. We can perpetuate discrimination, hardship and hypocricy, or we can finish the task which the Canadian Bill of Rights began.

\section{Labour Legislation}

Elsewhere in this paper the writer commented upon the Ontario recommendation to re-introduce Sunday observance legislation under the banner of provincial labour relations law. At that time, the concern was for the constitutional ramifications of such a "secularization". Now the question is whether it would be desirable.

The Ontario Report devotes considerable attention to research on the patterns of Ontario Sunday activity and the representations of its constituency interests. It is difficult to argue with statistics unless one has other statistics, for they too easily take on the meaning desired by those who quote them. With the greatest respect for the Ontario Commissioners, the writer cannot help but feel that they have acted judicially in the finest of tradition. The essence of their judgment is not a pearl from the wealth of their background information. It is found in such passing remarks as: ${ }^{178}$

It is in the light of this continuing erosion of statutory holidays and evening hours that we consider it absolutely essential that the government now attempt to preserve at least one uniform day each week as a pause day, before it is too late .... .

and "To suggest a day other than Sunday as a uniform day of pause for Ontario society would be to ignore history". ${ }^{177}$ It is respectfully submitted that these two statements form the nexus of the Ontario Report and are its starting point, not its conclusion.

That is not to say that the arguments presented are not perfectly cogent. On the contrary, this writer was deeply impressed by them. But the conclusion is still basically expeditious, still political, and still unsound.

Today's society is rapidly moving toward increased leisure time. The seven day week is a product of the past, the six day week is an anomaly and even the five day week is losing ground. To argue that a "pause day" must be legislated is to ignore that it is a reality. But serious exception is not taken to protective legislation of the sort which merely describes maximum working hours or days. Such protection already exists in the Alberta Labour Act.

The real difficulty with the Ontario Report is that it prescribes a single day as a uniform day of rest. The only real argument in favour of such a proposal is that it allows the whole family to be off work together. But this is not really as big a factor as the Commissioners would make it. In the first place, Canadian families are still predominantly supported by a single wage-earner, the feminist movement notwithstanding, and schools show no signs of increasing the days of classroom instruction. In fact, the reverse is the case for both overcrowded schools and automated industry. The second factor is the one singled out by the Report itself - Sunday has historically been a day off and it will probably remain so. In those occupations where Sunday work might increase, for instance, retail trade and manufacturing, the most realistic prediction is a three-to-four day work week with alternate shifts. The result for single-wage-earner families is more relaxation, not less, because business can divide its time with greater economy. And for the multiple-wage-earner family, the odds will be favourable that days-off can be co-ordinated most of the time.

176 Supra, n. 76 at 267.

177 Id. at 268. 
Even if there would be a problem with getting the family together or holding community events, both of which the writer feels are overstated, this is more than compensated for by the increased opportunity for better utilisation of recreational facilities, especially public parks. It is common knowledge that such resources are totally mismanaged in the present state of weekday silence and weekend madness. The freedom of even a small portion of the labour force, to pursue their recreation on a day other than Sunday, would be of greater lasting social and ecological benefit than the hypothetical preservation of family togetherness. Moreover, the emergence of a completely free marketplace would be to the consumer's advantage, abolishing the present vacuum of Sunday and allowing for more leisurely shopping. If, as is suspected, the large majority of the population will still retain Sunday as the day-off, shopping could prove to be a major leisure pastime and Sunday could even surpass other days of the week in net sales. In this respect, the argument of the Commissioners that prices would rise is on somewhat tenuous ground. It is also premised upon the concept of double-time pay for employees, which is not inevitable.

There are other advantages to be gained by removing the present prohibitions on Sunday work. Rendering Sunday contracts null and void, for instance, may have no bearing on the amount of work done on Sundays, but has drastic consequences. Even where work may be required, as for example in the real estate business, the Sunday laws do not always serve the needs of the people who want to examine prospective purchases at their leisure. Similarly, anyone with a steady job who has ever tried to visit a government agency during office hours will appreciate the advantage of staggered openings, including Sunday.

As a final argument, the writer would like to refer to the fact that never in its history has the State of California had a Sunday law of any significance. It is not to be inferred that our social climate is completely the same. But it is of great interest that this huge State, with a population roughly equivalent to all of Canada and a work force as equally diversified, has not seen the need for protective legislation in this area. Rather, it has founded itself upon principles of unrestrained commerce and religious freedom. Isn't it interesting that the majority of the population rests on Sunday, and even has time for church?

\section{CONCLUSION}

This paper has attempted to give the reader some insight into the legal foundation of Sunday observance legislation and its bearing on the question of freedom of religion. The present legislation was examined together with its history and the cases which have interpreted it. The constitutional validity of both the federal and provincial Acts was investigated. The writer has also commented upon the direction which Parliament and the Legislature should take in the future.

This is not an easy area of the law. It is rich in history, argument and policy. But a decision must be made. It will always prove to be a weighing of alternatives, a judging of the relative merits of uncomplementary arguments. Society must be properly regulated, the working force must be refreshed and families must have time to be together. But equally society must refrain from imposing standards which can, however wrongfully or innocently, be misinterpreted or which cause unnecessary discrimination and hardship. The dilemma was succinctly characterized by Mr. Justice Douglas of the United States Supreme Court: ${ }^{178}$

The question is not whether one day out of seven can be imposed by a State as a day of rest. The question is not whether Sunday can by force of custom and habit be retained as a day of rest. The question is whether a State can impose criminal sanctions on those who, unlike the Christian majority that makes up our society, worship on a different day or do not share the religious scruples of the majority.

The writer has no hesitation in agreeing with His Honor that it may not.

${ }^{178}$ McGowan v. Maryland, supra, n. 149 at 561. 